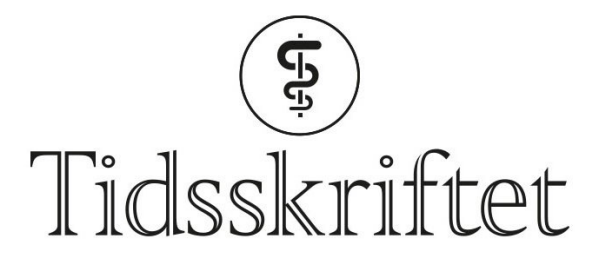

DEN NORSKE LEGEFORENING

\title{
Liv og død
}

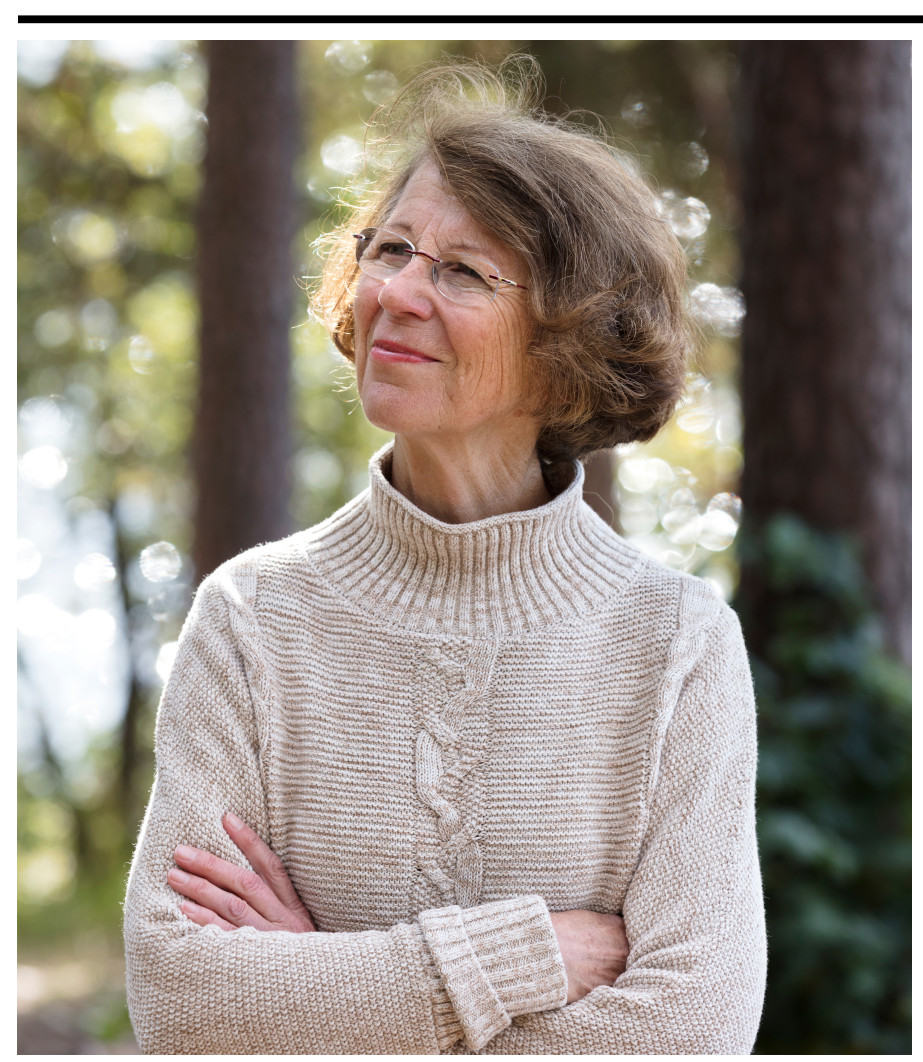

INTERVJU

\section{MARIT TVEITO}

Alderspsykiatrisk avdeling Diakonhjemmet Sykehus

Geriater Ildri Kjølseth har behandlet flere eldre som hadde gjort selvmordsfors $\emptyset$ k. Arbeidet med å forstå hva som hadde skjedd, ledet frem til en doktorgrad om hvorfor noen eldre velger å avslutte livet.

Den nå pensjonerte geriateren sier ja til å bli intervjuet etter å ha tenkt seg litt om. Da hun setter seg ned ved bordet i bibliotekbaren på Bristol, sier hun: - Når man har passert 70 år, må man bare si ja til ting.

- Er du blitt tøffere med årene?

- Nei, jeg tror ikke det. Man har mer erfaring, men blir også mer sårbar. Og så har man ikke samme krefter som tidligere, konstaterer hun.

Hun synes allikevel at dette er en mulighet til å formidle noe om det hun har vært opptatt 
av. Kjølseth har aldri vært redd for å si det hun mener. Overlegen skrev leserinnlegg da hun mente det var nødvendig, som da helsetilbud for eldre var truet av nedleggelse og omorganisering. En kollega omtaler hennes som den beste klinikeren hun kjenner og som en overlege som alltid har vært genuint opptatt av hva som er vesentlig for pasientene å få hjelp med. Utenom arbeidet, som har fylt mye av hennes liv, har hun et rikt nettverk av venner. Hun liker å reise, lese og lære nye ting.

\section{En rød tråd}

Kjølseth visste alltid at hun skulle bli indremedisiner.

- For meg var det indremedisin som var å være lege. Jeg begynte ved Haukeland universitetssykehus i 1971, jobbet så ved Akershus universitetssykehus før jeg begynte på Radiumhospitalet og tok spesialitet i onkologi i tillegg.

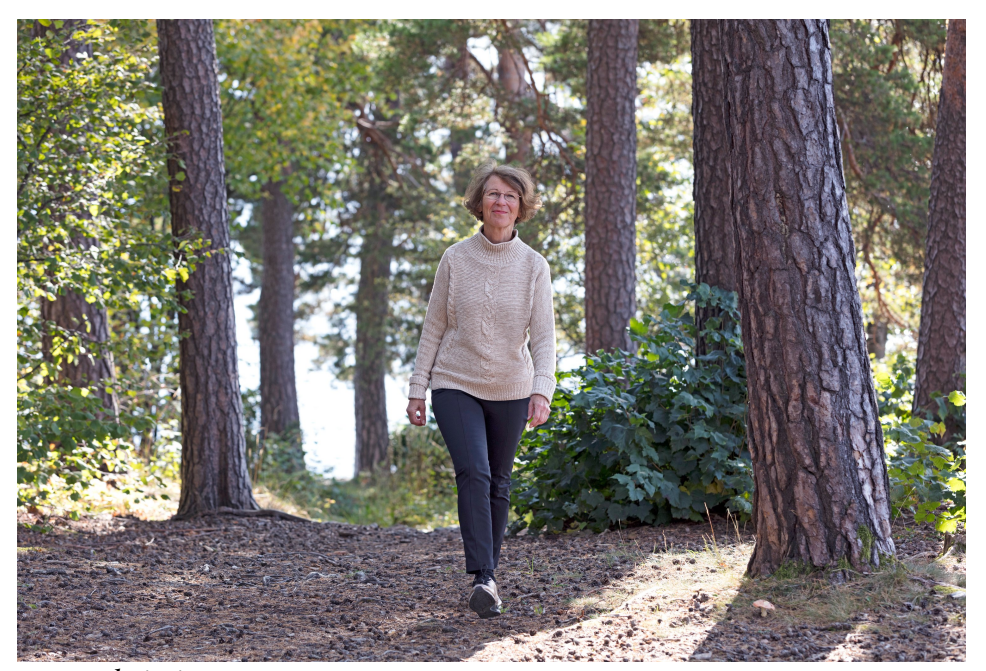

Foto: Christian Tunge

Dagens situasjon med kamp for faste stillinger i sykehus er lett gjenkjennelig for den pensjonerte overlegen. - Det var vanskelig å få fast stilling den gang også, og en overlegestilling kunne du bare håpe på før fylte 50 år. Etter hvert ble det allikevel overlegestilling ved medisinsk avdeling ved Ullevål universitetssykehus, sier hun.

- Krohgstøtten, byens eldste sykehus, hadde vært nedlagt en stund. Så vedtok politikerne at det skulle gjenåpnes under geriatrisk avdeling ved Ullevål. Jeg ble bedt om å ta fatt på oppgaven og reiste ned. Der var det kun et par sykepleiere igjen av staben. Vi bygde opp avdelingen fra bunnen. Det var en tid preget av entusiasme. Vi så hvordan eldre begynte å få mer avansert behandling ved innleggelse i sykehus, men også at man hadde glemt rehabiliteringsbehovet i etterkant. Vi etablerte samarbeid med bydelene, og etter hvert hadde vi en akuttpost hvor eldre med funksjonssvikt kunne innlegges direkte.

Kjølseth har vært gjennom mange sykehusomorganiseringer opp gjennom årene.

- Først ble avdelingen nedlagt, flyttet til Ullevål, nedlagt på nytt og gjenåpnet i det geriatriske bygget, konstaterer hun megetsigende.

- Du visste etter hvert at du ville bli indremedisiner, men har du alltid villet bli lege?

- Jeg visste at jeg ville ha en utdanning hvor jeg kunne forsørge meg selv. Jeg ønsket meg også et yrke hvor jeg kunne føle meg nyttig. Familien forventet nok heller at jeg skulle velge ingeniørstudier.

Både faren og bestefaren var ingeniører. Moren var sosialøkonom, en litt uvanlig utdanning for kvinner på den tiden. Mormoren ble enke da moren var ett år gammel, noe som kanskje understreket viktigheten av å kunne stå på egne ben for familiens kvinner.

- En familielege frarådet meg imidlertid å velge medisinen. Han trodde det ville være altfor tøft for meg. Og i perioder er det tøft å være lege, det hadde han jo rett i. 


\section{Doktor i en god tid}

- Jeg begynte å jobbe i en tid hvor man fortsatt trodde på generalistene, selv om debatten om grenspesialisering hadde startet.

Det manglet ikke på gode forbilder.

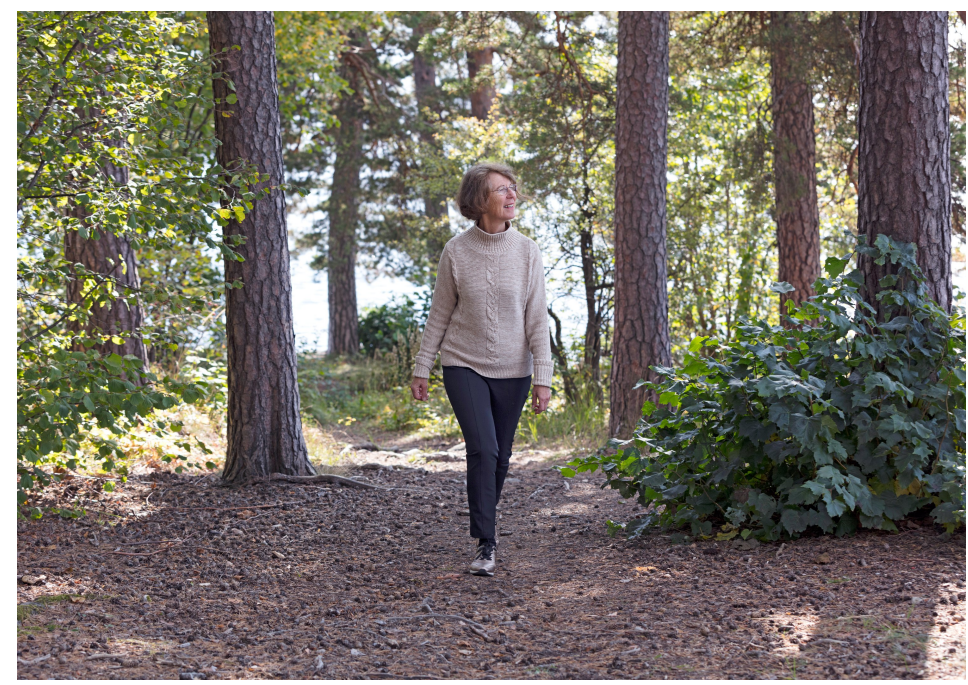

Foto: Christian Tunge

- Jeg møtte overleger som hadde spesialområder de var gode på, men de var dyktige og generelle klinikere samtidig. Jeg ble veldig godt ivaretatt av de gamle, erfarne overlegene. Vi hadde rom for diagnostisk diskusjon om vanskelige tilfeller. Det var intellektuelt utfordrende og stimulerende. I diagnostikkmøtene bestemte vi oss for utredning og valgte hvilke prøver som skulle tas. Det var et merkbart skille da laboratoriet fikk en autoanalysemaskin. Plutselig fikk vi masse prøvesvar, og i stedet for å tenke først, ble alle pasienter screenet med en rekke prøver ved innleggelsen. Det snudde om på rekkefølgen i hvordan man gjør ting. Jeg likte godt at vi måtte tenke først.

- Hva savner du fra yrkeslivet?

- Samarbeidet på avdelingen var særlig godt. Vi hadde sekretærer med yrkesstolthet, som kunne gi tilbakemelding hvis vi hadde diktert noe som burde rettes litt på. Kvaliteten på arbeidet var et felles prosjekt. Jeg hadde mer tid til å være doktor. Vi følte alle et stort, nesten voldsomt ansvar for pasientene og avdelingen. Samtidig hadde vi en myndighet som naturlig fulgte med det ansvaret vi var gitt.

I en periode hadde hun også lederoppgaver. I Ullevål-nytt fra 1992 kan du lese om Kjølseth og to andre kvinnelige leger som var sykehusets første tre kvinnelige avdelingsoverleger.

- Hvorfor sluttet du?

- Jeg syntes det ble tyngre og tyngre å være lojal mot de overordnede beslutningene. Vi opplevde konsulentenes inntog i sykehuset - de skulle omorganisere og legge ned sengeposter. Det var ikke så morsomt å være med i ledelsen etter hvert. Jeg har alltid ment at refleksjon er en viktig del av medisinen. Det virket som om ledelsen var mer opptatt av produksjon. Selv om pasientene var eldre mennesker med mange behov, kunne man få inntrykk av at det bare var utskrivningstallene som betydde noe.

Hun sier at hun hisser seg opp når hun hun snakker om eldreomsorgen. Det synes ikke. Hun er vennlig og mild i formen også når hun er engasjert.

- Eldre pasienter skal selvfølgelig også ha avansert behandling, men det er en forutsetning at man ivaretar funksjonene. Jeg blir opprørt over hvordan vi behandler gamle mennesker.

\section{Selvmord hos eldre}

Kjølseth nøyer seg ikke med å bli opprørt, hun blir også nysgjerrig. 
- Jeg tok en mastergrad i folkehelse ved Nordiska hälsovårdshögskolan i Göteborg. Der ble jeg interessert i kvalitativ forskning. En periode ble det innlagt flere eldre som hadde gjort veldig alvorlige suicidfors $ø$. Jeg gjorde en liten studie og intervjuet flere, under veiledning av psykiater Øivind Ekeberg. Det var store likheter ved historiene, og jeg fikk lyst til å jobbe mer med temaet. Så fikk jeg midler til å gjøre et større prosjekt. Det formet jeg slik jeg ville.

- Hva gikk det ut på?

- Jeg ville prøve å finne ut hvorfor eldre mennesker tar livet av seg.

- Hvordan skulle du gjøre det?

- Jeg reiste over hele Østlandet og intervjuet fastleger, pårørende og hjelpeapparatet rundt eldre som hadde tatt sitt eget liv. Det var en slags detektivjobb, hvor jeg skulle bli kjent med et menneske i etterkant av selvmordet. Jeg fikk noen spennende resultater, som jeg også fikk noen år til å formidle før jeg gikk av med pensjon. Jeg syntes det var både lærerikt, tankevekkende og trist.

Teen blir høytidelig servert i en forseggjort tekanne, og i bakgrunnen spiller noen Memory fra musikalen Cats på piano. Kontrasten til skjebnene Kjølseth har nøstet i er stor.

- Hva fant du i studien din?

- Jeg fant at eldre som tar sitt liv, ofte er viljesterke og handlekraftige mennesker som har hatt mye kontroll over sin egen situasjon. Denne kontrollen har nok vært tett knyttet til opplevelsen av egenverdi. Før selvmordet var de i en fase hvor de hadde mistet funksjon eller så at de kom til å gjøre det.

- Hvordan var det å nøste i historiene?

- Jeg følte etter hvert at jeg nesten forsto pasientene, av og til for godt. En del av det som hadde sviktet, var ofte forholdet til helsevesenet, og det var sørgelig. De fikk ikke den hjelpen de hadde trengt, og jeg tror det hadde betydning for flere av dem.

- Hvordan skal man hjelpe disse menneskene?

- Det handler ikke nødvendigvis om de vanskelige eksistensielle samtalene. Det handler mer om å se hva som er hovedproblemet og målrettet hjelpe med nettopp det, på en måte som ivaretar pasientens verdighet.

- Var det noe som gjorde særlig inntrykk?

- En kvinne hadde vært gjennom mye, blant annet behandling for kreftsykdom. Hun hadde en nydelig hage med en vakker rosebusk, og uansett i hvor dårlig form hun var, pleide hun å gå ut for å se den når den blomstret. Så klarte hun ikke lenger å komme seg ut av sengen. Hun hadde følt seg svært hjelpeløs og formidlet det til hjemmesykepleien - også det at hun hadde tanker om å ta sitt eget liv. Da jeg oppsummerte materialet, fant jeg at nesten to tredeler av pasientene hadde varslet om hva de kom til å gjøre. Omgivelsene hadde allikevel ikke tatt det på alvor. Av og til kunne det nesten virke som de hadde møtt forståelse for at de $\emptyset$ nsket å dø, og det syntes jeg var noe av det verste. Et menneske som føler seg verdiløst, blir enten ikke trodd - eller blir møtt med at valget aksepteres.

- Gjorde du deg tanker om din egen alderdom da du jobbet med disse som hadde valgt å forlate livet?

- Som yrkesaktiv tenkte jeg ikke så mye på det, jeg var mer opptatt av pasientene.

Alderdommen nå til dags er for de fleste forbundet med en sprek og lykkelig forlengelse av voksenlivet. Så kommer det allikevel en siste fase som er annerledes, og jeg ønsker meg mer verdighet i denne fasen av livet. Selvmordene illustrerer hvor redde vi er for å bli gamle og trenge hjelp. Det kan være en skremmende tanke, så den prøver jeg å holde unna.

- Hvordan gjør du det?

- Jeg har begynt å studere igjen. Det holder meg ung.

- Hva leser du? 
- Jeg studerer litteraturvitenskap. Jeg har alltid likt å lese, og det er fint å drive med noe annet enn fag. Nå leser jeg de bøkene jeg alltid har følt at jeg burde ha lest. Jeg liker å gå på kafé også, men man kan jo ikke bare gjøre det, smiler hun.

Kjølseth er glad i både friluftsliv og reising. Hun er nettopp kommet hjem fra en lengre tur til Canada. Turer til Nord-Norge, der hun bodde de første årene av livet, er også noe hun setter pris på.

\section{Samfunnsansvar}

- Vi som jobbet med eldre, trodde litt naivt at den demografiske utviklingen talte for seg selv - at vi som samfunn var nødt til å ta tak i helsehjelp til denne gruppen. Hvordan samfunnet behandler de eldre, påvirker i stor grad oss som skal bli gamle. Det er nok ikke blitt slik vi hadde sett det for oss.

\section{Ildri Kjølseth}

- Født 29. oktober 1945

- Cand.med. Universitetet i Oslo 1970

- Spesialist $\mathrm{i}$ indremedisin 1978

- Spesialist i onkologi 1981

- Spesialist i geriatri 1991

- Mastergrad i folkehelse 1997

- Ph.d. ved Universitetet i Oslo 2010

- Forfatter av boken Selvmord hos eldre, 2014

- Du gikk til både historien og filosofien da du arbeidet med selvmord?

- En svensk historiker, Birgitta Odén, slo fast at selvmordshyppigheten er et uttrykk for hvordan et land ivaretar sine eldre. Det gir klare signaler nedover i rekkene - samfunnet må kunne gi trygghet til alle i de siste leveårene.

- Hva slags trygghet?

- Vi må kunne gi hjelp på en måte som gjør at den eldre fortsatt føler seg verdifull. Og vi må gi trygghet for at man kan bevare verdigheten i den situasjonen man kommer i.

Hun blir oppgitt over at 103-åringer som ønsker seg sykehjemsplass, ikke får det, men enda mer over helsepersonell som offentlig støtter en slik vurdering.

- Jeg tror man har mistet noe vesentlig når man som helsepersonell forsvarer at man tilbyr «velferdsteknologi og trygghetsalarm».

- Må eldre klare seg for lenge hjemme?

- Aktivitetslinjen ble viktig etter hvert, det merket vi godt i arbeidet med eldre. Vi skulle jobbe med funksjonen slik at de skulle kunne klare seg hjemme. Det er ikke alltid det beste. Noen eldre er redde eller svimle - og fortjener en bedre og tryggere avslutning på livet. En venninne av meg døde i fjor. På en uke var det 27 ulike mennesker fra hjemmesykepleien innom henne.

- Hva skal vi som helsepersonell gjøre?

- Vi er kanskje for lojale overfor beslutninger som blir tatt? Kanskje må vi la være å skrive ut skrøpelige pasienter før vi har gjort en grundig nok jobb. Eldre trenger tid. Man tenker jo litt når man er blitt pensjonist. Før i tiden skrev jeg leserinnlegg. Jeg vet ikke om noen får 
lov til det lenger, sier hun litt spørrende.

- Er du fornøyd når du ser tilbake?

- Jeg synes jeg har fått brukt meg godt faglig. Jeg har likt å få utfordringer, selv om de av og til har vært i overkant, men de har alltid vært utviklende.

- Du har møtt mange mennesker i alvorlig sykdom og krise.

- Jeg lurte på om du ville spørre meg om hvorfor jeg valgte et såpass tungt tema for doktorgraden. Jeg vet ikke. Min mor fikk en progredierende nevrologisk sykdom da jeg var student, og hun ble etter hvert svært hjelptrengende. Det har nok bidratt til å forme meg som lege. Uansett hvor mørk en situasjon virker, er det alltid noe vi som helsepersonell kan bidra med for å hjelpe. Det er det viktig å huske på.

Publisert: 28. november 2017. Tidsskr Nor Legeforen. DOI: 10.4045/tidsskr.17.0841

(C) Tidsskrift for Den norske legeforening 2020. Lastet ned fra tidsskriftet.no 